\title{
МОНГОЛ ТЭРЛЭГ ЭСГЭХ АРГАД ХИЙСЭН СУДАЛГААНЫ ДҮН
}

О.Эрдэнэчимэг ${ }^{1}$

\author{
${ }^{l}$ Урлаг, биеийн тамирын сургууль, МУБИС, Монгол улс
} Цахим шуудан: о_erdeneus@yahoo.com

Summary: Delicacy of Mongolian deels can be clearly seen in deels of royal family members and nobles whose deels embedded typicals of the Central khalkh people. Since ancient times, our ancestors have created their own craft techniques of livestock items during their life in nomadic way at the vast steppe. It has been become rich heritage of ethnic handcrafts from generation to generation.

Tүлхиүр үг: Дээл, тэрлэг, эсгуҮр, энгэр, нударга, өргөн хормой, хэлбэр

Бидний өвөг дээдэс эрт үеэс өргөн уудам тал нутагтаа нүүдэллэн аж төрөхдөө амьдарлын хэрэглээний зүйлсийг өөрсдийн гараар урлах арга ухааныг бий болгож үеэс үед өвлөгдөн хөгжсөөр ардын гар урлалын баялаг өв сан болсон байна.

Монгол эрдэмтэд ардын гар урлалын өв сан, тухайлан дээл тэрлэгний талаар судалсан ажил, бүтээлээс дурьдвал Г.Бадрах ${ }^{1}$ монгол эртний дээл, тэрлэгний хэв загвар, мөн олон ястны хувцасны талаар Х.Нямбуу ${ }^{2}$, Г.Батнасан ${ }^{3}$ нар монгол үндэсний хувцасны өөрчлөлтийг түүхэн талаас, С.Бадамхатан ${ }^{4}$ монгол олон ястаны хувцасны онцлог талаас, Д.Баяр ${ }^{4}$ монголчуудын хүн чулууны дурсгал, XIII зууны дээл, Доржсүрэн ${ }^{5}$ археологийн олдвор, эртний Хүннү үеийн хувцасны эдийн соёлын талаас, Г.Цэрэнханд ${ }^{6}$ монголын эртний хувцасны талаар, Б.Дунгаамаа ${ }^{7}$ монгол дээлийн эсгүүр гаргах үйл явцыг автоматжуулах програм зохион бүтээсэн, Н.Норжинхорлоо ${ }^{8}$ их дээд сургуульд дээл хийх, О.Өнөрмаа ${ }^{9}$ ЕБС-ийн сурагчдад баривч оёх сургалтын хөтөлбөр боловсруулсан байна. М.Амгалан, Д.Нансалмаa ${ }^{10}$, Т.Дисан ${ }^{11}$, А.Оюунтунгалаг ${ }^{12}$, А.БаасанхүҮ ${ }^{13}$ нар монгол үндэстэн ястангуудын дээл, хувцасны өвөрмөц онцлогийн талаар

1. Бадрах Г.Чингисийн дээд үеийн Монгол хувцасны өгҮҮлбэр.УБ., 2006.

2. Нямбуу Х. Монгол хувисыг судалсан нь эл судалгааны арга зүйн үндэслэл.УБ., 1978.

3. Батнасан Г.Халх ястаны хувцасны түүхийн асуудал "Этнографийн судлал” УБ., 1987, Монгол ардын хувиас. УБ., 1989.

4. Бадамхатан С. БНМАУ-ын Угсаатны зүй. I Боть.УБ., 1978, Монголын угсаатны зүйн хээрийн судалгааны эх хэрэглэгдэхүҮн. I,II,III,IV,V Боть УБ.,2011.

5. Баяр Д.Монголчуудын чулуун хөрөг.УБ.,2002, Монгол нутаг дахь хүн чулуун хөшөө.УБ., 2001.

6. Доржсүрэн Ц.Умарт ХҮннҮ. УБ., 1961.

7. Цэрэнханд Г.Монголчууд:Угсаа соёл, зан заниил.ІІ БотьУБ., 2005.

8. Дунгаамаа Б. Монгол дээлийн судалгаа, боловсруулалт. Нэг сэдэвт зохиол.УБ., 2004.

9. Норжинхорлоо Н. Монгол дээл эсгэх, оёх сургалтын технологийн уламжслал, иинэчлэл. УБ., 2004.

10. Өнөрмаа О. Монгол үндэсний хувцас хийх уламжлалт технологийн сургалтын арга зүйн судалгаа.УБ.,2012.

11. Дисан Т. Монгол улсын Ховдын өөлдүҮд.ТҮҮх угсаатны зүйн судалгаа.УБ., 1999.

12. Оюунтунгалаг А.Монгольнн буриадууд. УБ., 2004.

13. БаасанхҮҮ А. Монгол алтайн бүс нутгийн ард түмний эдийн соёл. УБ., 2000, Монгол ойрадуудын соёл. УБ.,2010. 
бичсэнийг онцолж байна.

Монгол угсаатны ахуйн соёлын нэг гол илрэл бол хувцас хийх арга ухаан, түүнийг эдэлж хэрэглэх ёс заншил бөгөөд өнөө хир үндсэн агуулгаа хадгалсаар байгааг дээрхи судлаачид нотолжээ.

Монгол ардын гар урлалыг дотор нь: бөс даавуу, торгон эдийн урлал, эсгий ширмэлийн урлал, арьс ширэн эдлэлийн урлал, дарханы урлал, модон эдлэл, нарийн мужааны урлал гэсэн чиглэлээр ангилж болохоор байна.

Бөс эдийн урлалын тухай судалгаанаас үзэхэд оёдол үйлийг урлах аргын ашигтай нь амьдралын явцад шалгаран өвлөгдөн үлдэж, нийгмээ даган улам шинэчлэгдэж, ихээхэн боловсронгуй болжээ. Эртний монгол эмэгтэйчүүд өдөртөө сүҮ саалийн зав зайгаар, мал хариулж байхдаа, үдэш дэнгийн гэрэлд үйл мэтгэж, үр удамдаа өвлүүлж ирсэн түүхтэй.

Монголчууд дээл тэрлэгийн гадуурх эдийг өнгө, гадар, хуулга гэж нэрлэдэг байна.Тэрлэгний өнгө авлаа, тэрлэгний өнгө, дотор эсгэх, өнгө эмжих гэж ярьдаг. Харин үстэй дээлийн хувьд гадар, хуулга солих гэж ярьдаг байна. Бөс эдээр хийсэн бол давхар тэрлэг, дан тэрлэг гэж нэрлэнэ. Дотортой (давхар) тэрлэг өнгө, эмжээр, цаваг, дотор гэсэн дөрвөн төрлийн эдээс тэрлэг бүтнэ. Харин өнгө, эмжээр, цаваг гэсэн гурван төрлийн эдээс дан тэрлэг бүтнэ. Өнгө, дотрын завсар хөвөн, орчин үед зулхай тавьж оёсноор хөвөнтэй дээл бүтнэ. Өнгө дотрын дунд хөвөн жигд зулж хавж оён хөвөнг тогтооно. Үстэй дээл гадар, эмжээр, цаваг, үслэг эд (хурга, ишиг, ямааны арьс, хонины нэхий, туулай, гөрөөс, минж, булга г.м ангийн арьс) дөрвөн төрлийн эдээс бүтнэ. Үч дээл гэж гадуураа бөс эдээр өнгөлсөн дээлийг нэрлэнэ.

Монголын язгууртан, энгийн хүмүүсийн өмсөх дээл, тэрлэгийн хэв загвар хийц хоорондоо ялгаатай хэдий ч эсгэж оёх, ерөнхий зарчим адил байна. Монголчуудын оёдол үйлийн уламжлал монголын бүх үндэстэн, ястанд нийтлэг хамаарах бөгөөд язгууртаны эдлэж хэрэглэж байсан дээл, тэрлэг бусад оёмол өмсгөлүүдийн түүхий эдийн нэрийг хувцасны хуулиас шүүж хүснэгтээр үзүүллээ.

\begin{tabular}{|c|c|c|}
\hline 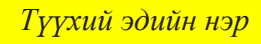 & Гарвал & Тайлбар \\
\hline Манног & торго & $\begin{array}{l}\text { Торгоны хаан манног торго юм. Манног торгыг дотор нь } \\
\text { алтан манног, хати манног гэж хуваана }\end{array}$ \\
\hline Таж & торго & $\begin{array}{l}\text { Монголчуудын зохиосон торго гэсэн мэдээ байдаг. Нууц } \\
\text { товчоо зохиолд гардаг. Өндөр Гэгээн Занабазарын асааж } \\
\text { байсан тэрлэг Богд хааны ордон музейд бий. }\end{array}$ \\
\hline Нагши & алтан хоргой & $\begin{array}{l}\text { Сувдат нагши (их сувдыг алтан хоргойд дарж оёсон) алтан } \\
\text { щар, улаан. Сувдат танам (тэрмэн) хүрэн }\end{array}$ \\
\hline $\begin{array}{l}\text { Бандагийн } \\
\text { мандарин }\end{array}$ & алтан хоргой & Энэ талаар хараахан мэдээлэл олдсонгүй \\
\hline Химарлиг & хамба хилэн & $\begin{array}{l}\text { Хар өнгөтэй байна. Өндөр мяндагтан лам хуваргуудын зах } \\
\text { сум эмжинэ. Үүнийг хиаз гэж нэрлэнэ. }\end{array}$ \\
\hline Хурмаш сиймхий & $\begin{array}{l}\text { эсгий (нимгэн } \\
\text { эсгий) }\end{array}$ & $\begin{array}{l}\text { Алтан хатгамалт(луут таваг өнгө)их улаан, хөх, ногоон, } \\
\text { мөнгөн, бор, цагаан бор, } \\
\text { Алтан луут хар хурмаш, Алтан хээт }\end{array}$ \\
\hline Пүрпүр & ноосон нэхмэл & Эсгийгээр хийсэн дээл \\
\hline Гүсүм & торго & $\begin{array}{l}\text { Балба улсын торго галд шатадгүй торго. Богд хаан ийм } \\
\text { тэрлэг гуталтай байсан мэдээ бий. }\end{array}$ \\
\hline
\end{tabular}




\begin{tabular}{|l|l|l|}
\hline Жашир & хоргой & Энэтхэг улсын хоргой, бас европ хоргой гэхэн ч бий. \\
\hline Төвэд хоргой & хоргой & $\begin{array}{l}\text { Хамгийн бөх хоргой. Сарлагийн үс, торгийг хольж нэхнэ. } \\
\text { Голдуу улаан өнгөтэй байна. }\end{array}$ \\
\hline Бороон (хялгасан) & торго & Энэ талаар хараахан мэдээлэл олдсонгүй \\
\hline Хятад шанги & торго & Голдуу шар өнгөтэй байна. \\
\hline Цэмбэ & даавуу & Алтан хээтэй, одончуу, тэрэм, даалимба, цууямбуу \\
\hline Дурдан & торго & МинчүҮ, чинчүҮ, чисчүҮ, хялгасан торго. \\
\hline Тэрэм & даавуу & Сарлагын үсээр хийнэ. \\
\hline
\end{tabular}

Эдгээр түүхий эдээр монголчууд тэрлэг бусад хувцас урладаг байжээ. Монголчууд торго дурдан нэхэж хийхээсээ илүүтэйгээр малын арьсыг боловсруулахдаа илүү сайн гаршиж монгол өрх бүр үйлдвэрлэгч байсан юм.

Агуу зүйл энгийн гэдэг. Монгол дээл, тэрлэг зохион бүтээсэн арга маш энгийн мөртлөө гүн гүнзгий утга агуулсан, монгол дээл, тэрлэгний ур хийц монголын язгуурын алтан ургынхан болон ноёд түшмэдийн дээл, тэрлэгийг уралсан байдал илүүтэй тод харагдах бөгөөд эдгээр хүмүүсийн дээл, тэрлэгүүд төв халхын дээл, тэрлэгний хэв шинжийг хадгалсан байна.

Монгол хүний өвөрмөц, онцлох шинж бол харааны ур, баримжаалах чадвар илүүтэй хөгжсөн байдаг нь бахархууштай, харамсалтай нь энэхүу сайхан уламжлалт чадвар олон нийтийг хамрахгүй цоохон хүмүүст хамааралтай болж алдагдаж байна. Хувьсгалт засаглалын эхэн үед Н.Чаушескуд монголд айлчлан ирэхэд тэрлэг бэлэглэхээр болжээ. Төрийн ордны өвгөн оёдолчин түүнд тэрлэг оёхоор зэхэж, холоос нэг харуулчихаарай гэсэн гэдэг. Урласан тэрлэг эзэндээ сайхан таарч хаанаас миний биеийн хэмжээг мэдэв ээ гээд гайхаж байсан гэдэг. ${ }^{14}$ Ямарч хүнийг хараад баримжаалан сайхан таарсан дээл, тэрлэг урлах чадвар монголчуудын дунд нийтлэг байжээ.

Монгол тэрлэг эсгэх уламжлалын онцлог бол биеэс хэмжээ авах арга юм. Хүний биеийн өндөр, өргөн хэмжээг төөлөхөд хэд багтаж байгаагаар тооцоолно. Гар хурууны хэмжээгээр дээл, тэрлэгийг биедээ тааруулж хийнэ. Хоёр гарын алдалсан хэмжээ тухайн хүний өндөртэй тэнцдэг алтан огтлолын хууль ${ }^{15}$ бий. Үүнийг дөрвөлжингийн онол гэх ба дээл, тэрлэг эсгэхдээ онолын үндэс болгоно.(зураг нэг а,б) Монголчуудын хэмжил зүй биедээ байдаг гэсэн яриа ч бий. Тэрлэг эсгэхэд бурхан зурах тигийн онолтой адил ${ }^{16}$ юм.

Хүний бие тэгш хэмтэй тул, биеийн урд талаас харсан байдлаар авч үзвэл эгэмийн хонхорхойгоор голч, ар талаас бол нуруу нугасны голоор голч болгоно. (Зураг г,Д) Тэрлэгний урт долоон төө эсгэдэг зарчим бий. (зураг д) Эхний төө шилэн хүзүүний долдугаар үеэс, доош чиглүүлэн 7 удаа төөлж уртыг олно. Арын голоос ханцуйны Үзүүр хүртэл дөрвөн төө, эсгүүрийг дэлгэхэд найман төө юм. (зураг д) Эртний монголчуудын дээл, тэрлэгний ханцуйг ихэд урт хийдгийн учир бол (зураг б) хүний гарын хэмжээ хязгаартайг, урт ханцуй хийж хягааргүй буян хишигийг бэлгэдсэн агуулгатай нисванс ${ }^{17}$, давхар сэрүүний улиралд гар даарч бээрхээс хамгаалдаг ахуйн хэрэгцээнээс үүдэлтай байна. Гарын

14. Нямбуу Х. Монгол хувиасны түҮх. УБ., 2002.

15. Пармон.Ф.М.Композииия костюма.М., 1985, Нямбуу Х.Монгол хувиасны түҮх.УБ., 2004, Дунгаамаа Б.Монгол дээлийн зохион бүтээлтийн судалгаа, боловсруулалт.УБ.,2000, Норжсинорлоо Н. Монгол дээл эсгэх, оёх сургалтын технологийн уламжлал, шинэчлэл.УБ., 2004, Сонгино Ч. Монголчуудынн үйл урлальн өв уламжлал. УБ.,2000, Өнөрмаа О.Монгол үндэсний хувиас хийх уламжлалт технологийн сургалтын арга зүйн судалгаа. УБ., 2012.

16. Мөн тэнд

17. Эрдэнэнчимэг О. Хувийн сан хөмрөг.Төвэд судлаач Ням-Очирын яриа.УБ., 2014.

$$
\text { - } 7 \text { - }
$$


урт хэмжээнд нэг төө нэг сөөм ${ }^{18}$ нэмж авна. Энэ нь дундчаар 30 см орчим юм. Ийм ханцуйтай дээл $\mathrm{XX}$ зууны эхэн үе хүртэл хэрэглэж байжээ. ${ }^{19}$ Дээл, тэрлэгний цээж, хормойн өргөн хэмжээг дараах байдлаар хэмжинэ. Уламжлалаар бол энгэр, арын голчоос нэг төө мөр болдог байна. Энэ нь зөвхөн биеийн хэмжээ тул дээр нь сулын хэмжээ нэмж хөдөлгөөнд саадгүй чөлөөтэй байхаар тооцоолно. Эрэгтэй хүний дээл, тэрлэгийг илүҮ өргөн хэмжээ тавих ба өмсөх эзэн махлаг, том биерхүү бол хэдэн хуруу хэмжээ нэмдэг байна. Эмэгтэй хүний дээл, тэрлэгийг арай бага хэмжээгээр эсгэнэ. Эдгээр аргыг монгол уран үйлчид, эмэгтэйчүүд маш сайн мэддэг байсан төдийгүй гэрийн эзэгтэй нар хань, үр хүүхэд, хамаатан садны галбирын онцлог, хоорондын ялгарах шинжүүдийг сайн мэдэх тул нэгийг нь нөгөөтэй харьцуулан жишиж өөрийнхөө гараар хэмжиж, өмсөх эзэнд тааруулахдаа насны онцлог, галбирт тохируулна. Нилээд сайн уран үйлчин өмсөх хүний биеийг хэмжих бол, арай дутмаг туршлагтай үйлчид уг хүний сайхан таардаг тэрлэгээс хэмжээ авна ${ }^{20}$. Тэрлэг эсгэхдээ өмсөх хүний галбир, биеийн хэмжээг үндэслэн хэдий хэмжээний бөс эд хүрэлцээтэйг тооцоолно.

Сурвалжаас шүүж үзэхэд бидний өвөг дээдэс дээл, тэрлэг эсгэх олон аргын тухай эрт дээр үеэс ам дамжин, мөн бичиж үлдээсэн байна. Бөс эдийн хээ, судлыг тааруулан, хаягдалгүй эсгэх олон аргуудыг амьдралын туршилгаас бий болгожээ. Бөс эдээр дотортой, доторгүй тэрлэг эсгэж, арьс, үнэт үс, нэхийгээр дээл эсгэх арга бүр ч өвөрмөц ур ухаан шаарддаг байна. Энэ удаад дээл эсгэх тухай орхиж, тэрлэг эсгэх талаар судалгаанаас үндэслэн тайлбарлахыг хичээлээ.

Монголын угсаатан судлал, хувцас судлаачдын бүтээлд бөхтөрч, ухаж, битүу талаас ухаж, таллаж, голлож, гүйлгэж, ташаалдаж, хүҮ энгэртэй, зөрүүлдэж, хараа гаргаж, эн уралдуулж эсгэх 11 аргын тухай ${ }^{21}$ тэмдэглэн үлдээсан байна.

Өнөдөөр ард түмний дунд нийтлэг дэлгэрсэн 2 аргаар тэрлэг эсгэдэг байна. Сурвалжаас хувцас судлалын мэргэжилтэн, эрдэмтэдийн тэрлэг эсгэх онолын 8 арга бол бөхтөрч-ухаж эсгэх-битүу талаас ухаж эсгэх, голлож-үйлгэж эсгэх, ташаалдаж, ХүY энгэртэй, зөрүүлдэж, хараа гаргаж, таллаж, эн уралдуулж эсгэх байна. Бусад арга нь нийгэм түүхэн хөгжлийн явцад гээгдэн хэрэглэгдэхээ болжээ. Тэрлэг эсгэх аргууд монгол үндэстэн ястангуудын хэл ярианы соёлоос хамааран өөрөөр нэрлэх тохиолдол байна.

Л.Батнасан, Ө.Өнөрмаа, Н.Норжинхорлоо нар бөхтөрч эсгэх, Б.Дунгаамаа, М.Цэрэнханд, Б.Шүрэнцэцэг нар ухаж эсгэх, Н.Норжинхорлоо битүҮ талаас ухаж эсгэх аргууд угтаа нэг аргын тухай бичжээ. Голлож -гүйлгэж гэж ярих болов ч нэг аргыг хоёр өөрөөр нэрлэсэн байна.

Х.Нямбуу голлон, бөгтөрч, зөрүүлдэж, эн зэрэгцүүлж ${ }^{22}$ эсгэх дөрвөн аргыг дурьдаж, зэрэгцүүлж эсгэх аргын талаар тайлбарлахдаа, эдгээр аргуудыг монголын уран үйлчид өнөөдөр хэрэглэсээр байгааг онцолсон байна.

Г.Батнасан ${ }^{23}$ голлож, бөгтөрч,

18. Эрдэнэнчимэг О. Хувийн сан хөмрөг. Норжинхорлоогийн Н. яриа, УБ., 2013.

19. ХХ зууны эхэнд авхуулсан “Халх гэр бүл” сэдэвт фото зурагт язгууртан эмэгтэй эхнэр дээл өмссөн, эрэгтэй хүҮхэд, хоёр залуугийн хамтад тэдгээрийн өмссөн дээлийн ханиуй ихэд урт эсгүүртэй байгаа нь илтэд доторхой харагддаг. Түүнчлэн үндэсний төв музейд байдаг бор торгон гадартай иэнхэр өнгийн дотортой дээлийн хэмжээс гэрчилнэ.

20. Эрдэнэчимэг О. Хувийн сан хөмрөг.

21. Нямбуу Х.Монгол хувиасны түҮх. УБ.2002, Дунгаамаа Б.Монгол дээлийн зохион бүтээлтийн судалгаа, боловсруулалт.УБ., 2000, Норжонхорлоо Н. Монгол дээл эсгэх, оёх сургалтын технологийн уламжлал, шинэчлэл.УБ., 2004, Сонгино Ч. Монголчуудын үйл урлалын өв уламжлал.УБ., 2000. Цэрэнханд М. Монгол дээл эсгэж оёх арга. УБ., 1983, Шүрэниэиэг Б.Монгол дээл эсгэх аргууд. УБ., 2008, Баасансүрэн А.Монгол алтайн бүс нутгийн ард түмний эдийн соёл.УБ., 2000

22. Нямбуу Х.Монгол хувиссыг судалсан нь. Эл судалгааны арга зүй үндэслэл. УБ., 2000. 
зөрүүлдэж, эн зэрэгцүүлж эсгэх аргуудын талаар бичиж, хоорондын ялгааг тодотгон тайлбарлажээ.

Ч.Сонгино ${ }^{24}$ тэрлэгийг зөрүүлдэж эсгэх, өргөн энтэй эдээр гүйлгэж, нарийн энтэй бол эн зэрэгцүүлж эсгэх тухай тайлбарлаж, эсгүүрийг зургаар үзүүлжээ.

Б.Дунгаамаа ${ }^{25}$ уламжлалт таван аргыг судалгаанаас үндэслэн бөс эдийн эн (өргөн, нарийн), бөс эдийн ялгаа (хээтэй, цулгуй), тэрлэгний урт, богиноос хамааралтай болохыг онцолж, хэдий үед хэрэглэж байсан он тооллыг мөшгөн судалж, зургийн хамт тайлбарласан бол “Дээл” номонд ХүY энгэртэй эсгэх аргын тухай дурьдаад ХүY оруулж энгэр залгаатай эсгэдэг гэж бичсэн байна.

О.Өнөрмаа ЕБС-ийн сурах бичигт ${ }^{26}$ орчин үеийн хувцас зохион бүтээх томьёонд тэрлэг эсгэх аргачлал боловсруулсан нь монголчууд төдийгүй дэлхийн улс орны хүмүүс монгол тэрлэг хийх боломжийг олгожээ.

О.Өнөрмаа өөрийн бүтээлдээ тэрлэгийг ташаалдах, бөгтрөх, голлох аргуудаар эсгэдэг тухай дурьдаад хамгийн хэмнэлттэй, хялбар арга нь зөрүүлдэж эсгэх гэж дүгнэн, зөрүүлдэж эсгэх аргыг тайлбарлажээ. Мөн монгол уламжлалт уран үйлд суралцах аргаас ${ }^{27}$ номонд хүүхдийн баривч эсгэж оёх талаар бичиж, тэрлэг эсгэх долоон арга бий гээд тэрлэг эсгэх аргуудыг өөрийн хуримтлуулсан туршлагад үндэслэн баяжуулан бичсэн байна. Нарийн энтэй 6.5 м урттай бөс эдээр тэрлэг эсгэхдээ таллаж эсгэх аргын хэрэглэнэ ${ }^{28}$ гэж 7 аргаас таллаж эсгэх тухай дэлгэрүүлэн бичсэн нь шинэ мэдээлэл болжээ. Н.Норжинхорлоо ${ }^{29}$ бөгтөрч, ташаалдаж эсгэх талаар товч дурьдаж битүу талаас ухаж, гүйлгэж, зөрүүлдэж эсгэх аргуудыг зургаар илэрхийлэн тайлбарласан бол М.Цэрэнханд ${ }^{30}$ ухаж, голлож, зөрүүлдэх гурван аргын тухай дэлгэрэнгүй бичиж зургаар илэрхийлсэн байна. Ухаж эсгэх аргыг XX зууний дунд үеэс эхлэн одоо болтол хэрэглэж байна ${ }^{31}$ гэж онцолсон байна.

О.Эрдэнэчимэг, М.Цэрэнханд ${ }^{32}$ ухаж, зөрүүлдэх, ташаалдах, голлож эсгэх дөрөв арга нэрлээд ухаж, зөрүүлдэх аргыг сургалтанд хэрэгжүүлэх заах арга зүйг боловсруулж тайлбар зургийн хамт оруулсан нь ЕБС-ийн технологийн хичээлээр сурагчид судалж, тэрлэг, баривч эсгэх аргад суралцаж байна. Б.Шүрэнцэцэг ${ }^{33}$

23. Батнасан Г.Монгол ардын хувиас. УБ., *Голлож эсгэх арга нь дээл, тэрлэгний өнгийг өргөн энтэй даавуу эдийн энгүй талаас ухаж эсгэхийг хэлнэ. Бөгтөрч эсгэх нь маш өргөн энтэй эдээр тэрлэгний өнгөний ханиуй сугыг шууд ухаж эсгэх арга юм. Дээлий нарийн энтэй бөсөөр эсгэх бол зөрүҮлдэж эсгэх аргыг голчлон хэрэглэнэ. Дээлийг зөрүҮлдэж эсгэх үед бөс эдийн нэг нугалаа нь ар, нөгөө нэг нугалаа нь гадаад энгэр, дутуу нугалсан нугалаа нь дотоод энгэр болохоор тохируулж 3 нугалаад эсгэдэг. Эн зэрэгиүүлж эсгэх нь эдийг энтэй талаар зэрэгиүүлэн тавьж, дээл, тэрлэгний гадар өнгө эсгэхийг ингэж хэлдэг” гэжээ.

24. Сонгино Ч.Монголчуудын үйл урлахуйн эрдэм, ухаан.УБ., 1999.

25. Дунгаамаа Б.Монгол дээлийн зохион бүтээлтийнсудалгаа,боловсруулалт. УБ., 2004. **Ташаалдаж эсгэх нь монгол дээлийн анхны эсгүYр бөгөөд VIII-XIV зууныг дуустал хэрэглэгдэж байсан. XV зууны Үеэс ухаж эсгэх арга шинээр нэвтэрснээс хойш бараг хэрэглэхээ больжээ. Мөн ухаж эсгэх арга нь ХV зуунаас манайд хэрэглэж эхэлсэн юм. Энэ аргыг тухайн үед бүх төрлийн бөс эдээр дээл эсгэхэд баримталдаг байснаа ХX зууны сүҮлчээр зөвхөн өргөн энтэй даавуу, торгон бөс эдээр дээл эсгэхэд ашигладаг болсон байна" гэжээ. ХІХ зууны эхээр нарийн энтэй бөс эдийг хэрэглэж эхэлснээр дээл эсгэх иинэ арга - голлож эсгэх буюу гүйлгэж эсгэх арга бий болжээ. Энэ аргын давуу тал нь өргөн, нарийн ямар ч энтэй бөс эдээр дээл эсгээ болдог гэжээ. Тэрээр зөрҮҮлдэж эсгэх арга нь ХХ зууны дунд үеэс бий болсон гэжээ..

26. Өнөрмаа О.Хөдөлмөр сургалт 8-р ангийн сурах бичиг УБ., 1987.

27. Өнөрмаа О.Монгол уламжлалт уран үйлд суралцах аргаас.УБ., 2006.

28. Өнөрмаа О.Монгол үндэсний хувиас хийх уламжлалт технологийн сургалтын арга зүйн судалгаа.УБ.,2012.

29. Норжинхорлоо Н.Монгол дээл эсгэж оёх, сургалтын технологийн, уламжлал шинэчлэл.УБ., 2006.

30. Цэрэнханд М.Монгол дээл.УБ., 1983.

31. Цэрэнханд М.Монгол үндэсний хувияас. УБ., Монгол дээл.УБ., 1983.

32. Эрдэнэчимэг О,Цэрэнханд М.Зохион бутээх хөдөлмөр.VIII ангийн сурах бичиг.УБ.,2004.

33. Шүрэниэиэг Б.Монгол дээл эсгэх аргууд. УБ.,2011. 
хараа гаргаж эсгэх тухай бичжээ. Нарийн энтэй бөс эдээр эн зэрэгцүүлж, ташаа оруулж эсгэнэ. Монголын зарим нутагт голлож эсгэх аргыг бөгтөрч эсгэх гэж ярьдаг. Багадуу бөс эдээр гүйлгэж эсгэнэ. Онцлог нь дотоод энгэрийг гүйлгэж, залгаатай хийнэ. Энэ нь арга биш аргачлал юм гээд шинээр нэг арга нэмэж бичээд эл аргаар хэрхэн тэрлэг эсгэхийг тайлбарлаж, зургаар илэрхийлсэн байна.

Судлаачдын бичвэрээс тэрлэг хийх бөс эдийн төрөл хоорондын ялгаанаас хамаарч тэрлэг эсгэх найман арга байна. Эдгээр аргуудыг шинжлэн судалж олны хүртээл болгох нь чухал юм.

Монгол дээл, тэрлэг гадаад энгэр, дотоод энгэр, ар, зах, ханцуй нударга гэсэн хэсгээс бүрдэнэ. Монгол тэрлэгийг сайтар бодож, нягт нямбай эсгэдэг тул үйлчид тэрлэг эсгэсний дараа өөдөс бараг үлдэхгүй, эгэл атлаа нарийн эсгүүр хийцтэй байдаг нь ихэд гайхамшигтай юм.

Эдгээр аргуудын талаар угасаатан судлалын эрдэмтэд, хувцас судлаачид, оёдолчдын ном, тэмдэглэлээс мөшгөн судалсанаар, мөн өөрийн хуримтлуулсан мэдлэгт тулгуурлан дараах дүгнэлтэнд хүрлээ. Ерөнхийдөө тэрлэгний өнгө (бөс эдийн) эн 80-90 см өргөн хэмжээтэй бол тэрлэг эсгэж оёоход өмсөх хүний өндөр намаас хамааран 4-6 м торго, дурдан орно. Дугуй хээтэй бол хээг нийлүүлэхийн тулд арай илүү бөс эд орно. Хээгүй, өргөн энтэй бөс торго бол зөрүүлдэж эсгэнэ.

Тэрлэгийг төрөл бүрийн өргөн нарийн энтэй $45 \mathrm{~cm}-50 \mathrm{~cm}, 70 \mathrm{~cm}, 90 \mathrm{~cm}-110 \mathrm{~cm}$, 140 см-150 см хэмжээтэй бөс эдээр эсгэдэг байна.

Бөс эдийг давхарлан нугалж, үндсэн утасны чиг дагуу тэрлэгийн урт байхаар нэг талд нь эсгүүр зурна. (зураг г эсгэнэ). Өөр нэг арга бол эзэндээ сайхан таардаг тэрлэгийн урт хэмжээгээр бөс эдээ нугалж, нэг талыг өвөр нөгөө нугалсан талыг ар тал болгон эсгэнэ.

Бөс эдээ дэлгэж ханцуйн уг, суганы өргөн, мөр, ханцуйн үзүүрийн өргөн эдгээрийг хэмжин зурна. Ташааг зурахдаа хормойн өргөнийг хэмжин толбон тэмдэг хийнэ. Долоо хэмжиж нэг огтол гэсэн ардын мэргэн сургаалаар, дахин хэмжилт эсгүүрийг шалгаж чавхаар ором гаргах, эсбол эсгүүрийн шохой, савангаар толбон тэмдэгүүдийг шугамын тусламжтай холбон зурж хайчилна.

Дээрх аргуудаар дугуй хээтэй торгоор тэрлэг эсгэхэд оёдлын залгаaс таарах хэсэгт бүтэн хээ байхаар тааруулна. Дугуй хээ мөрөөр бүтэн байхаар энгэр, ар ханцуйг үргэлж эсгэнэ. Ханцуйны үзүүр хэсэгт заавал зүйдэл орно. Хээтэй торго ихэвчлэн нарийн энтэй байдаг. Иймд бөс эдийн энгийн хэмжээнээс хамаарч ташаа оруулж эсгэх, эн зэрэгцүүлж эсгэх, зөрүүлж эсгэх аргуудаар тэрлэг эсгэнэ. Хээтэй бөс эдээр тэрлэгний өнгө эсгэхдээ дугуй хээ тааруулахыг ихэд чухалчилна.

Торго дурдангийн уртад хэен ${ }^{34}$ талд, тал дугуй хээтэй бол энгэр, арын голын оёдолд бүтэн дугуй хээтэй байхаар заавал тааруулж эсгэнэ. Харин хоёр хэен талд бүтэн хээтэй байвал бөс эдийн хүртээмжээс хамаарч бүтэн дугуй хээг, эгнээ зэрэгцүүлсэн эсвэл ташуу байрлуулж эсгэнэ. Ингэхдээ дээл,тэрлэгний энгэрт дугуй хээ гурвалжин байрлалтай байхаар тааруулна энэ нь түшиг тулгатай, бат бэх, буян хишиг тогтохын бэлгэдэл гэж эрхэмлэнэ. Орчин үед зарим үйлчдийн урласан дээл, хантаазны цээжин дэх дугуй хээний байрлал доошоо харсан гурвалжин дүрстэй байдлаар эсгэсэн байгаа нь хаяа ажиглагддаг. Өвөг дээдсийн энэхүУ сайхан бэлгэ дэмбэрэлтэй, утга санаа агуулсан уламжлал мартагнаж тогтворгүй дүрс бэлэгдэлийг агуулсан байгаа нь судалгааны явцад ажиглагдаж байна.

Мөн хормойд дугуй хээ тэгш дүүрэн, мөн тулгатай байхаар тааруулна. Хормойн орчим, ташааны хэсгээр зүйдэлгүй байхаар өгзөгнөөс доош, хормойн ирмэг хүртэл бөс эдийн энгийн өргөнөөр хормойн өргөн хийнэ, хэрэв шаардлагатай бол дотоод

34. Эрдэнэчимэг.О.нарын.Технологи ІІ. сурах бичиг.УБ., 2007. 
энгэрийг хээ тааруулж гүйлгэж эсгэнэ. Ерөнхийдөө дугуй хээ энгэрийн гол, ар нурууны гол, хоёр мөрөнд тааруулна.

Бөс эдэд зурсан эсгүүрийн хэмжээг дахин сайтар хэмжиж шалгана. Тэрлэгийг их бие, гадаад энгэр, зах, ханцуйн зүйдэл, нударга, эмжээр, хажлага, дотор гэсэн эрэмбэ дарааллаар эсгэнэ. Зах оёж бэлтгээд дараа нь их биед зах байрлах хэсэгт, захны урт хэмжээгээр тааруулан ухаж хайчилна.
Дээл, тэрлэгний уртыг бүсэнд орох шингээлтийг бодолцон нэмнэ. Эртний монголчууд дээл, тэрлэгний ар хормойг урд хормойноос нэг төө урт хийдэг байжээ. Ар хормой урт байх нь бие хөнгөрхөд хаалтын үүрэг гүйцэтгэнэ. Эзэн хүн дээл, тэрлэгээ өмсөж бүс бүслэхдээ хормойг огшоодог тул адилгүй урттай ${ }^{35}$ хормой анзаарамгүй харагдана.
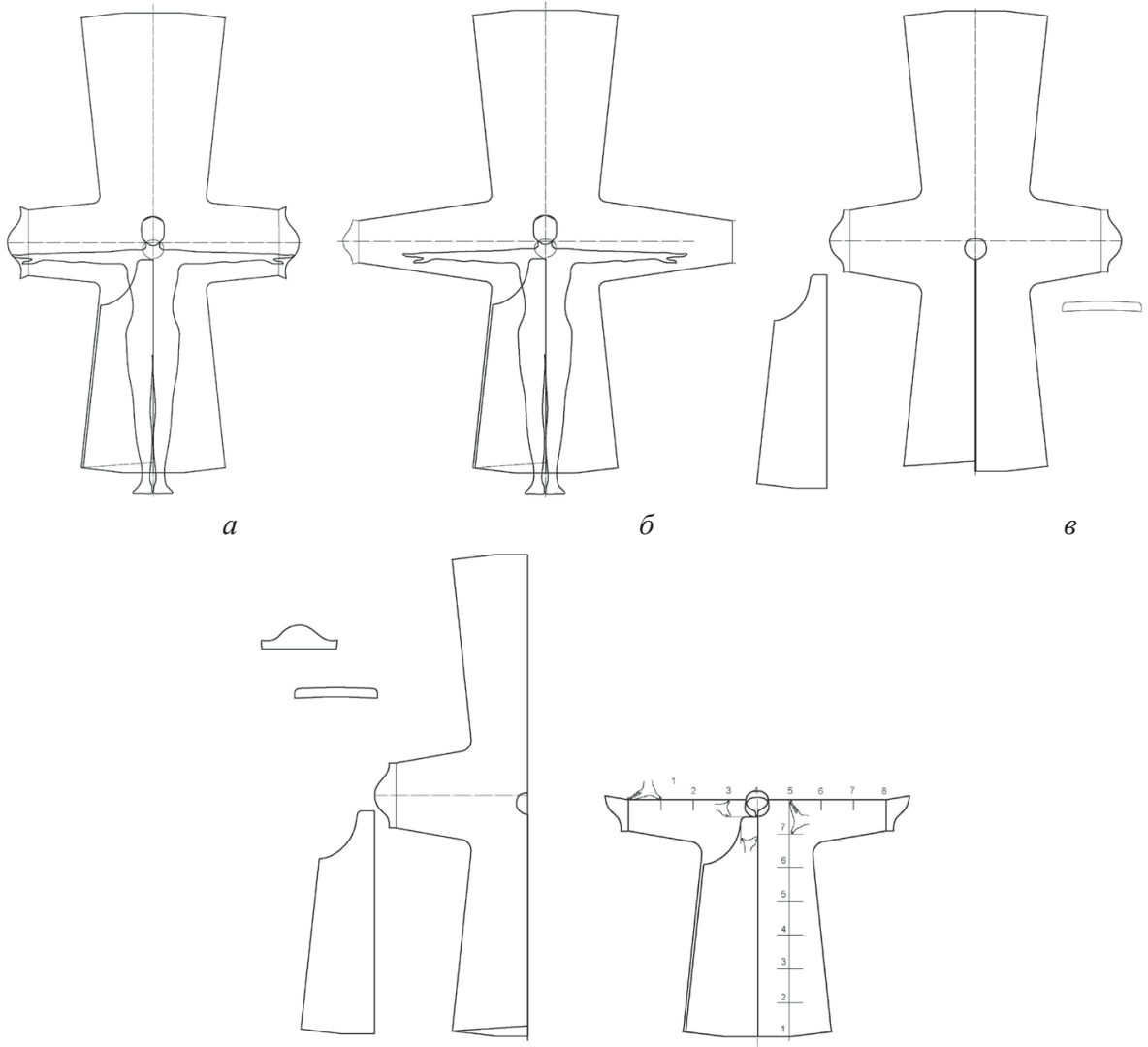

2

$\partial$

Зураг 1. Монголчуудын уламжлалт дөрвөлжингийн онол.

a/ Орчин үеийн тэрлэгний эсгуҮр. б/ ХХ зуун түҮнээс өмнөх үеийн тэрлэгний эсгүҮр.

в/ Тэрлэгний эсгуҮр дэлгэсэн байдал г/ Хүний бие тэгшхэмтэй тул эсгүүр зургийг бөс эдийн нэгталд зурна. Тэрлэгний бүрдэлд их бие, гадаад энгэр, зах, нударга. д/монголчуудын уламэслалт гар хурууны хэмжүүрээр төө хэмжүурээр дээл тэрлэг бүтээх онол

35. Саруулбуян Ж,Энхтуяа Л, нарын Монголчуудын хувиас.УБ., 2012. Үндэсний музей. Дархад эрэгтэй дээл. д/ де Ү2008-9-2. Урт 162 см, Цээжний тойрог 77 см, Саруулбуян Ж, Энхтуяа Л, нарын Монголчуудын хувиас. УБ.,2012, Аюуш Ц. Монгольн угсаатны зүйн хээрийн судалгааны эх хэрэглэгдэхүҮн.1973 онд Дорнод аймгийн Матад суманд ажсилласан угсаатнй зүйн хээрийн судалгааны тайлан, эх хэрэглэгдэхүҮн III Боть УБ.,2011. 
Орчин үед тэрлэгний ханцуйн уртыг эрхий хурууны эхний үе хүртлэх хэмжээ авч эсгэдэг байна. Энэ нь европ гадуур хувцасны хэмжил зүйн хэмжээ авах аргачлалтай адил байна. Нудрагатай хийх бол нударганы урт, ханцуйн өргөнтэй ижил, нударганы өргөн гарын долоон хуруу хэмжээ байна. Цээжний өргөн эсгэхэд хүний биеэс цээжний бүслүүрийн хэмжээ авч, уг хэмжээг дөрөв хуваагаад дээр нь 6 см нэмнэ. Эмэгтэй хүнийх бол 4 см хэмжээ нэмвэл тэрлэг эзэндээ сайхан таардаг байна. Жишээлбэл: Хүний биеийн цээжний бүслүүрийн хэмжээ (Цб)112 см бол 112 см:4+6 см=34 см байна. Эмэгтэй хүний дээл бол $100 \mathrm{cm:4+4} \mathrm{cм=29} \mathrm{см.} \mathrm{Энэ}$ хэмжээ цээжний өргөний хагас болно. Хормойн өргөн хэмжээ олохдоо цээжний өргөний хагас болох 34 см дээр 6 см нэмэхэд хормойн өргөний хагас хэмжээ болно. Ахмад настан хүний өмсөх тэрлэг бол цээжний хэмжээнд дээр 8 см нэмнэ. Хормойн өргөлт 1 см байна. Хормойны өргөн ингэж олох ба хормойн өргөлтийг нэг см хэмжээтэй ташаа талаас дээш өргөлт хийж эсгэвэл хормой, ташаагаар унжихгүй. Мөрний шугамаас 15 см доош гадаад энгэр байрлана. Тэрлэгний гол шугамаас баруун тийш дан бөс эд байрлуулан гадаад энгэр эсгэнэ. Уламжлалт аргаар энгэр эсгэх тухай Х.Нямбуу тэрлэгний энгэрийг харааны уртыг голоос баруун тийш хөндлөн мухар сөөм хэмжээтэй авч дорогш нь сугаруу татан ухлаадас гаргадаг ${ }^{36}$ гэжээ. Эл аргыг өдгөө ч хэрэглэсээр байдаг. Энгэрийн харааг манз гэж зарим нутагт нэрлэдэг. Хараа буюу манзыг дөрвөн хуруу хэмжээгээр авна. Өврийн ухаарыг баримжаалж эсгэдэг байсан бол одоо нийтлэг тооцооны аргаар эсгэх болжээ. Харааны төгсгөлийг цэгийг суганы цэгтэй холбож шугамдаж зурна. Зурсан шулуун хэрчимыг гурав тэнцүу хувааж тэмдэглэнэ. Суга талаас эхлэн тэмдэглэсэн цэгүүдийг шулуунаар зурсанаас доош перпендикулиар татаж, тэгш өнцөг үүсгэн доош 5 см хэмжээ, дараагийн тэмдэгээс 3.5 см хэмжиж тус тус тэмдэглэнэ. Эдгээрийг хараа, суганы цэгүүдийг холбож муруй нумалж зуран энгэр, өврийн ухлаадасыг эсгэдэг байна. Дараа нь хормойг чиглүүлэн доош ташааг хайчилж хараа, өврийн ухлаадас, сум эсгэнэ.

Захны ухаар эсгэх уламжлалт арга бол мөрний (бөс эдийг нугалж энгэр арын зааг) шулуунаас доош мухар сөөм, энгэрийн голоос баруун тийш мөн л мухар сөөм тэмдэглэж тэгш өнцөгт зурж дараа нь дугуйруулан зурна. Өөр нэг арга бол захны ижил урттай аяга хөмөрч тавиад аягаа тойруулж зурж ухаж хайчилна. Аяганы амсарын хэмжээнээс зах хоёр см орчим урт байвал илүҮ зохимжтой ${ }^{37}$ гэж үзнэ. Захны ухаарыг орчин үед дараах байдлаар эсгэнэ. Хүний биеэс хүзүүний бүслүүрийн хэмжээ авахдаа хүзүүний сууриар хэмжинэ. Авсан хэмжээг гуравт хуваана. Жишээ нь: захны ухаарын өргөн олохдоо хүзүүний бүслүүрийн хэмжээ 45 см бол 45 см:3=15 см бол захны ухаарын гүн олохдоо захны ухаарын өргөнөөс 2 см хасч олно. 15 см-2 см=13 см. Эдгээр хэмжээсийг холбон тойрог зурж, ухаж эсгэж том хүний тэрлэг бүтнэ.

Хүүхдийн тэрлэг, баривчны хүзүүны ухаар их, зах нилээд урт, нарийхан эсгэж, оёхдоо хатуулахгүй. Цээж тавиу, ханцуй өргөн, хормой богиндуу, бүчин товчлууртай нь том хүний дээл тэрлэгээс ялгарах шинжүүд юм. Товчлуурын хувьд заханд бүч хадахгүй, энгэр, хоёр суганд бүч хадаж ард нь зангидна.

Хүүхдийн баривч, тэрлэг урт зах, өргөн цээж, өргөн ханцуйтай хийдэг тул өмссөн хүүхдийн бие өсөж, баривч, тэрлэг нь тоодойж багадах үед цээжээр барихгүй, хөдөлгөөнд нь саад болдоггүй, удаан хугацаагаар өмсөх боломжыг бүрдүүлсэн байдаг нь монгол эмэгтэйчүүдийн уран ухаанаар гайхамшигтай шийдэж чаджээ.

36. Нямбуу Х.Монгол хувцасны түУх.УБ.,2002.

37. Өнөрмаа.О.Монгол үндэсний хувиас хийх уламжлалт технологийн сургалтын арга зүйн судалгаа.УБ.,2012. 
Монгол хүн үндэсний хувцас, дээл,тэрлэгийг ихэд дээдлэнэ. Үндэсний дээл, тэрлэг өмсөх ёс заншил эрт үеэс уламжилсан байдаг. Эсгэсэн бөс эдээ газар тавилгүй аль болохоор хурдан оёж дуусгахыг хичээнэ. Оёж дуустлаа бөс эдээс үлдсэн өөдсийг хаялгүй хадгалж байгаад бага зэрэг хоёр ширхэг өөдсийг галдаа өргөж галын бурханыг мялааж баярлуулдаг заншил бий. Энэ нь галын бурханд мөн адил торгон тэрлэг хийж өгч байна гэсэн санаа агуулдаг байна. Түүнчлэн тэрлэг эсгэхэд гарсан өөдсийг “үйл бүт”38 гэж хэлээд галд өргөнө. Харин тэрлэгээ оёж дуусахаас өмнө эсгүүрээс үлдсэн өөдөс даавуугаа хаявал үйл бүтэлгүйтнэ гэнэ. Түүнчлэн дээл, тэрлэгээ оёж байгаад түр амс хийх үед учигтай зүү орхилгүй зүүнд сүвэлсэн утсыг заавал дуустал оёно. Хэрэв учигтай зүҮ үлдээвэл дуусах хугацаа сунжирна гэдэг байна. Энэ нь аливаа зүйлийг хийж бүтээхдээ эсгэсэн зүйлийг цагт нь дуусгаж дараах ажилдаа ордог ахмадын бичигдээгүй хууль тул юмыг хугацаанд нь дуусгаж чаддаггүй үйлчинг муу үйлчин гэж үздэг. ${ }^{39}$ Ингэж монгол дээл, тэрлэгийг урлаж ирсэн уламжлалт арга бий.

\section{ДҮГНЭЛТ}

Даяаршлын үед монгол дээл, тэрлэг урлах ухааныг авч үлдэх, эртний монголчууд хэрхэн дээлээ урлаж ирсэн түүхийг баримтжуулах санаа агуулан судалгааны ажлаа хийсэн болно.

Монгол дээл, тэрлэгийн, оёдол үйлийн хөгжлийн уламжлал шинэчлэлийн асуудлыг угсаатны судал талаас судалсан арга зүйн үндэсийг тодруулах, археологийн эртний олдвор, музейд хадгалагдаж байгаа биет дурсгалуудыг харьцуулан судалж үндсэн хэрэглэгдэхүүн болгов. Г.Бадрах, Х.Нямбуу, С.Бадамхатан, Г.Цэрэнханд, Ц.Аюуш, Г.Батнасан, Д.Баяр, У.Эрдэнэбат, А.Баасанхүу Б.Мөнхцэцэг, Марко Поло, Л.Л.Викторова С.И.Руденко нарын бүтээлээс дээл, тэрлэгний хэлбэр, донж маяг, загварын хувьсал, бүрдэл хэсгүүдийн шинэчлэл, дээлийн түүхий эдийн шинжийг түүхэнталаас,Монголдээлийноёдолүйлийн дэвшил зохион бүтээлт, эсгэж оёх онол, арга зүй талаас С.Бадамхатан, Г.Цэрэнханд, Ц.Аюуш, Г.Батнасан, Н.Дунгаамаа, Ч.Сонгино, Н.Норжинхорлоо, О.Өнөрмаа, М.Цэрэнханд, нарын бүтээлүүдийг судлан бид түүх, угсаатны зүйн үүднээс задлан шинжилж нэгтгэв. Ингэхдээ монгол дээл, тэрлэгийг бүх талаас нарийвчлан судалж, түүнийг эсгэх, оёх, хэрэглэх түүхий эдийг боловсруулах зэрэг уламжлалт арга ухааныг орчин үеийн техник, технологийн дэвшилтэй холбож, улмаар хойч үедээ өвлүүлэн үлдээх гол зорилт байлаа. Эхний удаад дээл, тэрлэг эсгэх сэдвээр судалгаа хийж дүгнэлтээ гаргав.

Бурханы зураг тиг, дээл эсгэхэд баримтлах хүний биеийн хэмжээ авах ёс хоёрын аль аль нь хүн төрлөхтний гайхамшигт нээлт юм гэж ${ }^{40}$ Х.Нямбуу, Б.Дунгаамаа, О.Өнөрмаа нар тодорхойлсон байдагтай бид санал нэгдэж байна. Нүүдэлчин соёл иргэшилтэй монголчууд нүүдэл суудлын байдалд нэн тохирсон хэмжүүр биедээ агуулж явдаг онцлогтой. Гар хурууны хэмжээгээр хувцсаа урласаар ирсэн арга монгол хүний хэмжил зүйн уламжлалт хэв шинж, дадал юм. Тэрлэг эсгэх эдгээр аргуудыг нэгтгэн багцалж дүгнэхэд: эн зэрэгцүүлж эсгэх, таллаж эсгэх, ташаа оруулж эсгэх аргыг бөс эдийн

38. Монгол зан зүйлийн нэвтэрхий толь. Оюуны боть. Өвөр монгол. Улаанхад., 1999.

39. Сонино Ч.Монголчуудын үйл урлахуйн эрдэм ухаан. УБ., 1999.

40. Дунгаамаа Б. Монгол дээлийн судалгаа, боловсруулалт. УБ.,2004, Нямбуу Х.Монгол хувисыг судалсан нь эл судалгааны арга зүйн үндэслэл.УБ., 1978, Нямбуу Х.Монгол хувцасны түҮх. УБ., 2002, Өнөрмөө О.Монгол үндэсний хувиас хийх уламжлалт технологийн сургалтын арга зүйн судалгаа.УБ., 2002, Мөнхиэиэг Б. Монгол дээлийн эсгуҮрийн хувьсал хөгжил.УБ.,2009. 
эн нарийн бол хэрэглэнэ. Харин ухаж эсгэх, голлож эсгэх, хараа гаргаж эсгэх аргыг бөс эдийн эн өргөн бол хэрэглэнэ. ХүҮ энгэр залгаатай, зөрүүлдэж эсгэх эл аргаар бөс эдийн өргөн, нарийн эн хамааралгүй эсгэдэг байна. Харин хүY энгэртэй эсгэх эл аргаар эхнэр дээл эсгэхэд илүҮ тохиромжтой юм. ХүҮ энгэр зүйдэлтэй эсгэх тэр үеэс эхнэр дээлийн хэв маяг тогтсон байж магадгүй байна. Бас хормойг залгаатай эсгэх болсоноор тэрлэгэнд шинээр дэнхив бүрдэл нэмэгдсэн байна.

Ахмад настаны тэрлэгийг уужим, богиновтор эсгэж, өргөндүY эмжинэ. Нудрагатай хийх бол дэлбэн туурай, халбигардуу хэлбэртэй хийнэ.

Залуу хүний тэрлэгийг элбэгдүу, урт эсгэж, хос гурвалсан эмжинэ. Нударгыг цомбон туурай хэлбэртэй, жижгэвтэр байна.

Хүүхдийн тэрлэгийг томдуулан, тааруулан, багадуулан өмсгөх ба үүнийг элбэг дээлтэй хэвлүүхэн хүҮ, яг таарсан дээлтэй догь хүY, тоодойсон дээлтэй өхөөрдөм хүҮ гэж энхрийлнэ. Гурван цаг, үеийг хамаатуулсан баривч, тэрлэг биеийн хөгжил, хөдөлгөөнд саадгүй, богиндуу, удаан хугацаагаар өмсөх боломжыг бүрдүүлсэн, дулаахан байдаг нь том хүний тэрлэгэнээс ялгарах онцлог болно. Монголчуудын аман ярианаас үүдэлтэй хувцасны тоо гүйцчихнэ гэж зулай гишгэж төрсөн ах эгчийн хуучин баривч, тэрлэг ээлтэй гэж дүҮд шилжүүлэн өмсгөх уламжлал бий.

Эртний монголчуудын өмсөж эдэлж байсан хувцас өмсгөлийн түүхий эдийг тоочвол нагши, химарлиг, хурмаш, цэмбэ, пүр пүр, бандагийн мандарин, гүсүм, жашир, хятад шанги, манног торго, алтан манног, хати манног, хялгасан торго байна. Эдгээр нь зөвхөн алтан ургын язгууртан нар, төрийн албан хаагчдад хамаатай болно. Дээрхи дурьдсан түүхий эд өнөөдөр бидэнд үгүй, заримыг үндэсний музей, Богд хааны ордон музейнд цэмбэ, жашир, хятад шанги, манног торго, алтан манног, хати манног, хялгасан торго, арьс, эсгийгээр хийсэн дээл,тэрлэг бусад өмсгөлийг сонирхон үзэх боломжтой байдаг.

Судалгаанаас үндэслэн дээл, тэрлэгийг урлан бүтээх гурван үечлэлийг дараалан тоймлон багцлав. Зохицохуйн урлаг (дизайн, зохион бүтээхүй (эсгүүр), оёх (наах, хэлбэршүүлэх, хатуулах, холбох, төрөл бүрийн аргаар чимэх). Эдгээр нь хоорондоо нягт уяалдаатай, дээл, тэрлэгний гадаад үзэмж, хэрэглээнд гол нөлөөлнө. Энэхүу шат дараалсан гурван үйл ажиллагааны үр дүнд монгол дээл, тэрлэг бүтэх ба зориулалт хоорондын уялдаа, харилцан холбоог судлан бүдүүвчээр тодорхойлон авч үзвэл: 
I алхам: Зохицохуйн урлаг

\begin{tabular}{|c|c|}
\hline $\begin{array}{l}\text { Гадаад орчинтой } \\
\text { зохицохуй }\end{array}$ & $\begin{array}{l}\text { - } \quad \text { Улирлын шинж чанар: өвөл, хавар, зун, намар. } \\
\text { - } \quad \text { Хэрэглээ: өмсөх, ахуйн }\end{array}$ \\
\hline $\begin{array}{l}\text { Дотоод орчинтой } \\
\text { зохицохуй }\end{array}$ & $\begin{array}{l}\text { - } \quad \text { Бөс эдийн шинж чанар, өнгө, хээ судал } \\
\text { - } \quad \text { энгийн, гоёл, ямба ёслол }\end{array}$ \\
\hline $\begin{array}{c}\text { Хувь хүний } \\
\text { онцлогт зохицохуй }\end{array}$ & $\begin{array}{l}\text { - } \quad \text { нас намба, хүйс, галбирын онцлог } \\
\text { - } \quad \text { угсаа гарвал, хэргэм зэрэг }\end{array}$ \\
\hline
\end{tabular}

II алхам: Зохион бүтээх

\begin{tabular}{|c|c|}
\hline Бөс эд & $\begin{array}{l}\bullet \quad \text { эн, хэен, цулгуй, хээтэй, бөс эдийн төрөл } \\
\text { • } \quad \text { өнгө, дотор, хажлага, цаваг, эмжээр, наалт, оёдлын утас }\end{array}$ \\
\hline Эсгуүр & $\begin{array}{l}\bullet \quad \text { хэмжил зүй: уламжлалт, орчин үеийн } \\
\text { • } \quad \text { дээл, тэрлэг эсгэх аргууд, томёо, тооцоолол }\end{array}$ \\
\hline Багаж & $\begin{array}{l}\text { - } \quad \text { чавх, хайч, шөвөг } \\
\text { - } \quad \text { туузан метр, шугам, шохой хайч }\end{array}$ \\
\hline
\end{tabular}

III алхам: Oёх

\begin{tabular}{|c|c|}
\hline $\begin{array}{l}\text { Машины оёдол, } \\
\text { гар оёдол }\end{array}$ & $\begin{array}{ll}\cdot & \text { нэгтгэх, дан даруулах } \\
- & \text { хавах, хөвөрдөх, мэтгэлзэх, шидэх }\end{array}$ \\
\hline Гар ажиллагаа & $\begin{array}{ll}\cdot & \text { өөлөх, сэтлэх, тэмдэглэх, зурах, хайчлах } \\
\cdot & \text { шүлсдэж жилэмдэх, наax, сампин, шилбэ засах }\end{array}$ \\
\hline Хэлбэр олгох & $\begin{array}{l}\text { - хагалах, унагах, хүрээлэх, ирмэг чацуу нугалах, } \\
\text { шингээх, сунгах, хатуулах, } \\
\text { шувтрах }\end{array}$ \\
\hline
\end{tabular}

Дээрхи алхамуудаар оёдол үйлийн түүхэн хөгжлийн үр дүнд монгол эдийн соёлыг бүтээж язгууртан, энгийн хүмүүсийн өмсөх тэрлэгүүдийг урлаж иржээ. Энэ бол хувцасны зохион бүтээлт, технологийн ажилбарууд бөгөөд монголчуудын эрхэмлэн хүндлэж ирсэн чухал зүйлийн нэг бэлгэдэлээр илэрхийлэх зан үйлийн ёс заншил юм. Бэлгэдлээс үүдэлтэй дэлхийд цор ганц, монголын уран үйлчидийн ур ухаанаар бүтсэн чимэг оёдлууд утас эрчилж зээглэж оёх, зүү ороох оёдол, загсан нуруу, саа даруулж оёх, зүймэл урлалыг бүтээсэн байна. Монголчуудын ёсонд өдөр, цагийн сайныг сонгож үйл мэтгэх, сэтгэлийн илэрхийлэлийг бэлгэдэж ээжийн ерөөлөөр заяа буян тэгшлэх, төөрөг төөрүүлэх, гадны таагүй нөлөөнөөс хамгаалах дом, мэсийн хор тайлах, шинэ баривч, дээлийн мялаалга ${ }^{41}$, эвхэх, хадгалах, оёдол үйл мэтгэх ёс заншилыг илүүтэй чухалчилж иржээ. 


\section{Аиигласан бүтээлийн жсагсаалт}

1. Нямбуу Х. Монгол хувиасны түҮХ / УБ., 2002.

2. Дунгаамаа Б. Монгол дээлийн зохион бүтээлтийн судалгаа, боловсруулал / Техникийн ухааны доктор (Ph.D)-ын зэрэг горилсон бүтээл.УБ.,2000.

3. Бадамхатан С. БНМАУ-ын Угсаатны зүй. I Боть / УБ., 1978, Монголын угсаатны зүйн хээрийн судалгааны эх хэрэглэгдэхүҮн. I,II,III,IV,V Боть УБ.,2011

4. Аюуи Ц. Монголын угсаатны зүйн хээрийн судалгааны эх хэрэглэгдэхүүн (1973 онд Дорнод аймгийн Матад суманд ажилласан угсаатнй зүйн хээрийн судалгааны тайлан, эх хэрэглэгдэхүУн) ІІІ Боть /УБ., 2011

5. Норжинхорлоо Н. Монгол дээл эсгэх, оёх сургалтын технологийн уламжлал, шинэчлэл Боловсролын доктор (Ph.D)-бlн зэрэг горилсон бүтээл. УБ., 2004.

6. Сонгино Ч. Монголчуудын үйл урлалын өв уламжслал. Соёл судлалын ухааны доктор (Ph.D)-вын зэрэг горилсон бүтээл / УБ.,2000.

7. Ц Цэрэнханд М. Монгол дээл эсгэж оёх арга / УБ., 1983.

8. Шүрэниэиэг Б. Монгол дээл эсгэх аргууд /УБ.,2008.

9. Баасансүрэн А. Монгол алтайн бүс нутгийн ард түмний эдийн соёл / УБ., 2000.

10. Сонгино Ч. Монголчуудын үйл урлахуйн эрдэм, ухаан / УБ., 1999.

11. Өнөрмаа О. Хөдөлмөр сургалт 8-р ангийн сурах бичиг / УБ., 1987.

12. Өнөрмаа О. Монгол уламжлалт уран үйлд суралиах аргаас/ УБ., 2006.

13. Өнөрмаа О. Монгол үндэсний хувияас хийх уламжслалт технологийн сургалтын арга зүйн судалгаа /УБ.,2012.

14. Цэрэнханд М, Эрдэнэчимэг О.Зохион бутээх хөдөлмөр (VIII ангийн сурах бичиг) / УБ., 2004.

15. Пармон.Ф.М.Композииия костюма / М., 1985.

16. Саруулбуян Ж., Энхтуяа Л., нарын Монголчуудын хувиас / УБ., 2012.

17. Эрдэнэчимэг О., нарын.Технологи II (Сурах бичиг) / УБ., 2007.

18. Мөнхиэиэг Б. Монгол дээлийн эсгүҮрийн хувьсал хөгжил / УБ., 2009. 